\title{
CENÁRIOS DE OCUPAÇÃO URBANA E SEUS IMPACTOS NO CICLO HIDROLÓGICO NA BACIA DO CÓRREGO DO MINEIRINHO
}

Rubens de Miranda Benini

Dissertação apresentada à Escola de Engenharia de São Carlos da Universidade de São Paulo, como parte dos requisitos para a obtenção do Título de Mestre em Ciências da Engenharia Ambiental.

Orientador: Prof. Dr. Eduardo Mario Mendiondo

São Carlos

2005 